\title{
Front Matter: Volume 8040
}

, "Front Matter: Volume 8040," Proc. SPIE 8040, Active and Passive Signatures II, 804001 (6 July 2011); doi: 10.1117/12.901408

SDIE Event: SPIE Defense, Security, and Sensing, 2011, Orlando, Florida, United SPIE. States 


\title{
PROCEEDINGS OF SPIE
}

\section{Active and Passive Signatures II}

\author{
G. Charmaine Gilbreath \\ Chadwick T. Hawley \\ Editors
}

27-28 April 2011

Orlando, Florida, United States

Sponsored and Published by

SPIE 
The papers included in this volume were part of the technical conference cited on the cover and title page. Papers were selected and subject to review by the editors and conference program committee. Some conference presentations may not be available for publication. The papers published in these proceedings reflect the work and thoughts of the authors and are published herein as submitted. The publisher is not responsible for the validity of the information or for any outcomes resulting from reliance thereon.

Please use the following format to cite material from this book:

Author(s), "Title of Paper," in Active and Passive Signatures II, edited by G. Charmaine Gilbreath, Chadwick T. Hawley, Proceedings of SPIE Vol. 8040 (SPIE, Bellingham, WA, 2011) Article CID Number.

ISSN 0277-786X

ISBN 9780819486141

Published by

SPIE

P.O. Box 10, Bellingham, Washington 98227-0010 USA

Telephone +1 3606763290 (Pacific Time) · Fax +1 3606471445

SPIE.org

Copyright () 2011, Society of Photo-Optical Instrumentation Engineers

Copying of material in this book for internal or personal use, or for the internal or personal use of specific clients, beyond the fair use provisions granted by the U.S. Copyright Law is authorized by SPIE subject to payment of copying fees. The Transactional Reporting Service base fee for this volume is $\$ 18.00$ per article (or portion thereof), which should be paid directly to the Copyright Clearance Center (CCC), 222 Rosewood Drive, Danvers, MA 01923. Payment may also be made electronically through CCC Online at copyright.com. Other copying for republication, resale, advertising or promotion, or any form of systematic or multiple reproduction of any material in this book is prohibited except with permission in writing from the publisher. The CCC fee code is 0277-786X/11/ \$18.00.

Printed in the United States of America.

Publication of record for individual papers is online in the SPIE Digital Library.

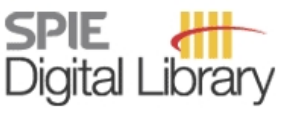

SPIEDigitalLibrary.org

Paper Numbering: Proceedings of SPIE follow an e-First publication model, with papers published first online and then in print and on CD-ROM. Papers are published as they are submitted and meet publication criteria. A unique, consistent, permanent citation identifier (CID) number is assigned to each article at the time of the first publication. Utilization of CIDs allows articles to be fully citable as soon as they are published online, and connects the same identifier to all online, print, and electronic versions of the publication. SPIE uses a six-digit CID article numbering system in which:

- The first four digits correspond to the SPIE volume number.

- The last two digits indicate publication order within the volume using a Base 36 numbering system employing both numerals and letters. These two-number sets start with 00, 01, 02, 03, 04 , $05,06,07,08,09,0 A, 0 B \ldots$. OZ, followed by 10-1Z, 20-2Z, etc.

The CID number appears on each page of the manuscript. The complete citation is used on the first page, and an abbreviated version on subsequent pages. Numbers in the index correspond to the last two digits of the six-digit CID number. 


\section{Contents}

$\checkmark$ Conference Committee

\section{SESSION 1 ACTIVE AND PASSIVE SIGNATURES}

804002 Developing composite signatures (Invited Paper) [8040-01]

C. T. Hawley, Signatures Support Program (United States); T. Carpenter, ASR, Inc. (United States); P. G. Cappelaere, S. Frye, J. J. Lemoigne-Stewart, D. Mandle, NASA Goddard Space Flight Ctr. (United States); S. Montgomery, A. Williams-Bess, ASR, Inc. (United States)

804007 2D signature for detection and identification of drugs [8040-04]

V. A. Trofimov, S. A. Varentsova, Lomonosov Moscow State Univ. (Russian Federation);

J. Shen, C. Zhang, Q. Zhou, Y. Shi, Capital Normal Univ. (China)

\section{SESSION 2 SIGNATURE MINING IN LARGE DATA SETS}

804008 Uncertainties of measures in speaker recognition evaluation [8040-06]

J. C. Wu, A. F. Martin, C. S. Greenberg, R. N. Kacker, National Institute of Standards and Technology (United States)

804009 Advances in the design, development, and deployment of the U.S. Army Research Laboratory (ARL) multimodal signatures database [8040-07]

K. Bennett, U.S. Army Research Lab. (United States); J. Robertson, Clearhaven Technologies LLC (United States)

\section{SESSION 3 ATMOSPHERIC SIGNATURES}

8040 OA Coherent uplink arraying techniques for next generation space communications and planetary radar systems [8040-26]

B. J. Geldzahler, NASA (United States)

8040 OC Next generation signature-based hyperspectral detection: a challenge to atmospheric modelers (Invited Paper) [8040-1 1]

A. Schaum, B. Daniel, U.S. Naval Research Lab. (United States)

\section{SESSION 4 UNIQUE APPLICATIONS}

$8040 \mathrm{OE}$ The optical performance of all-optical switching based on fiber Bragg grating [8040-13] Z. Zang, Kyushu Univ. (Japan); W. Yang, Harbin Institute of Technology (China) 
8040 OG Spectral variations in HSI signatures of thin fabrics for detecting and tracking of pedestrians [8040-15]

J. A. Herweg, Rochester Institute of Technology (United States) and Air Force Institute of Technology (United States); J. P. Kerekes, E. J. Ientilucci, Rochester Institute of Technology (United States); M. T. Eismann, Air Force Research Lab. (United States)

$8040 \mathrm{OH} \quad$ Spectral analysis algorithm for material detection from multispectral imagery [8040-16] J. K. Racine, Booz Allen Hamilton Inc. (United States) and Defense Intelligence Agency (United States)

\section{SESSION $6 \quad$ SIGNATURES FOR TERRAIN CHARACTERIZATION AND MAPPING}

8040 Ol Quantification of constituents in areal and intimate binary mixtures of particulate materials [8040-17]

M. S. West, R. G. Resmini, K. Manville, MITRE Corp. (United States)

$8040 \mathrm{OJ}$ Changes in apparent emissivity as a function of viewing geometry [8040-18]

C. J. Deloye, M. S. West, J. M. Grossmann, MITRE Corp. (United States)

8040 OK Complex soil electrical impedivity signatures [8040-19]

S. J. Ghionea, D. M. Hull, U.S. Army Research Lab. (United States)

8040 OL Crude oil, petroleum product, and water discrimination on terrestrial substrates with airborne imaging spectroscopy [8040-20]

C. S. Allen, George Mason Univ. (United States); M. P. S. Krekeler, Miami Univ. (United States)

\section{SESSION 7 DEPTH RECOVERY FOR 3D SIGNATURES}

8040 ON Efficient RPG detection in noisy 3D image data (Invited Paper) [8040-22]

F. Pipitone, U.S. Naval Research Lab. (United States)

8040 OQ Lidar signal depolarization by solid targets and application of polarimetric lidar to terrain mapping and 3D imagery [8040-24]

X. Cao, Royal Military College of Canada (Canada); G. Roy, Defence Research and Development Canada, Valcartier (Canada); R. Bernier, Les Instruments Optiques du St-Laurent Inc. (Canada); G. Tremblay, AEREX Avionics Inc. (Canada); S. Roy, C. Laflamme, Defence Research and Development Canada, Valcartier (Canada)

POSTER SESSION

8040 OS Analysis of reflectance characteristics of selected plants [8040-21]

M. Kaszczuk, Z. Mierczyk, M. Zygmunt, W. Piotrowski, J. Mierczyk, Military Univ. of Technology (Poland)

Author Index 


\title{
Conference Committee
}

\author{
Symposium Chair
}

William Jeffrey, HRL Laboratories, LLC (United States)

Symposium Cochair

Kevin P. Meiners, Office of the Secretary of Defense (United States)

Conference Chairs

G. Charmaine Gilbreath, U.S. Naval Research Laboratory (United States)

Chadwick T. Hawley, National Signature Program (United States)

Program Committee

Kelly W. Bennett, U.S. Army Research Laboratory (United States)

Carlos O. Font, U.S. Naval Research Laboratory (United States)

Herbert J. Mitchell, Naval Postgraduate School (United States)

Joseph E. Peak, U.S. Naval Research Laboratory (United States)

\section{Session Chairs}

1 Active and Passive Signatures

G. Charmaine Gilbreath, U.S. Naval Research Laboratory (United States)

2 Signature Mining in Large Data Sets

Carlos O. Font, U.S. Naval Research Laboratory (United States)

3 Atmospheric Signatures

Chadwick T. Hawley, National Signature Program (United States)

$4 \quad$ Unique Applications

Chadwick T. Hawley, National Signature Program (United States)

5 Spectral-based Signatures

Kelly W. Bennett, U.S. Army Research Laboratory (United States)

$6 \quad$ Signatures for Terrain Characterization and Mapping

Frank Pipitone, U.S. Naval Research Laboratory (United States) 
7 Depth Recovery for 3D Signatures

Michael West, MITRE Corporation (United States) 